\title{
The Influence of Trading Locations on Equity Returns
}

\author{
Nguyen N.T. Vo ${ }^{1}$ \\ ${ }^{1}$ Becamex Business School, Eastern International University, Binh Duong Province, Vietnam \\ Correspondence: Nguyen N.T. Vo, Becamex Business School, Eastern International University, Nam Ky Khoi \\ Nghia Street, Phu Hoa Ward, Binh Duong New City, Binh Duong Province, Vietnam. Tel: 84-(0)-650-2220341. \\ E-mail: nguyen.vo@eiu.edu.vn
}

$\begin{array}{lr}\text { Received: October 3, } 2016 & \text { Accepted: October 13, } 2016 \quad \text { Online Published: October 29, } 2016 \\ \text { doi:10.5539/ass.v12n12p188 } & \text { URL: http://dx.doi.org/10.5539/ass.v12n12p188 }\end{array}$

\begin{abstract}
This paper evaluates the impact of trading locations on equity returns by examining the stock price behaviour of three Anglo-Dutch dual-listed companies which result from mergers where two corporations agree to function as a single operating business, but maintain separate identities. The shares of these stocks are traded not only in their home market but also on several US stock exchanges in the form of American Depository Receipts. Regressing the return differentials on these dual-listed and cross-listed stocks on the relative market index returns and currency changes provides evidence of an apparent violation of the Law of One Price. The regression results show that the return on each part of dual-listed companies is highly correlated with the market on which it is most intensively traded. Similarly, returns on cross-listed stocks have considerably higher co-movement with US market indices and considerably lower co-movement with home-market indices than their home-market counterparts. Market risk premium is not a significant explanatory variable of the location of trade effect.
\end{abstract}

Keywords: trading locations, equity returns, law of one price, co-movement, dual-listed company, cross-listed company

\section{Introduction}

According to the Law of One Price (LOOP) two identical commodities should be priced at parity, because they are perfect substitutes (Lamont \& Thaler, 2003). If international financial markets are perfectly integrated, the same set of risky cash flows has the same value and risk characteristics when its trade is redistributed across markets and investors (Froot \& Dabora, 1999).

However, recent studies have shown that share price of a company is influenced by the market in which its stock is traded, which indicates the LOOP does not hold in actual financial market. For instance, Bodurtha, Kim, and Lee (1995) argue prices of closed-end country funds are strongly affected by U.S market movement, even though their net asset values are not. Froot and Dabora (1999) study pairs of "Siamese-twin" companies, or dual-listed companies (DLCs), whose stocks are traded around the world and find that the relative prices of twin stocks appear correlated with the markets where they are traded most.

Chan, Hameed and Lau (2003) investigate the case of the Jardine Group companies that shifted their listings from Hong Kong to Singapore in 1994. They find that Jardine stocks are more correlated with Singapore market after the delisting, although the core business of the group remained in Hong Kong.

This paper examines the impact of trading locations on equity prices by testing if the stock returns of DLCs are affected by the relative market indices, the relevant currency changes and the local market risk premium. Three examples of Siamese twins are investigated: 1) Royal Dutch Petroleum and Shell Transport and Trading plc; 2) Unilever NV and Unilever plc; and 3) Elsevier NV and Reed International plc over the period from 1980 to 2002. They are all Anglo-Dutch DLCs since the first parts of the twins mentioned above are from the Netherlands while the second parts are from the UK.

Table 1 provides a brief description of the three DLCs examined in the paper. 
Table 1. Descriptions of the DLCs

\begin{tabular}{lllll}
\hline DLC & Country $1 / 2$ & DLC Type & Analysed period & Unification Date \\
\hline Royal Dutch Shell & Netherlands/UK & Combined & $1.1 .80-3.10 .02$ & 20.7 .2005 \\
Unilever & Netherlands/UK & Separate & $1.1 .80-3.10 .02$ & - \\
Reed Elsevier & Netherlands/UK & Combined & $1.1 .93-3.10 .02$ & - \\
\hline
\end{tabular}

Note. DLC=Dual-listed company

This paper is organised in five sections as follows: the first two sections provide a brief introduction and an overview of the literature on mispricing behaviour and location of trade effect; the third section describes the research methodology and selected data; section four discusses the research findings; and section five presents the conclusions.

\section{Literature Review}

One of the first papers working on this topic was Rosenthal and Young (1990). They examine the pricing of shares of two Anglo-Dutch DLCs: The Royal Dutch Shell group and Unilever group for the period from September 1979 to December 1986. They document significant and persistent deviations from a specific ratio for the market prices of these securities implied in the "equalisation agreement" on both the New York and London exchanges. They found that the direction and magnitude of the mispricing are common to both pair of stocks and both markets.

Froot and Dabora (1999) study the price behaviour of the shares of three Siamese twins: Royal Dutch/Shell group, Unilever group and SmithKline Beecham group from 1989 to 1995. They show that twin price discrepancies are highly correlated with relative stock indices of the markets on which each stock has its main listing. They consider several potential explanations for this mispricing behaviour including the tax-induced investor heterogeneity, market-wide noise shocks from irrational traders and institutional inefficiencies. Nevertheless, none of them are able to give a full explanation.

Eun and Sabberwal (2002) examine the contribution of the US stock exchange to the price discovery of non-US securities cross-listed in the US. Specifically, they study a sample of 62 Canadian stocks listed on both the Toronro Stock Exchange (TSE) and the US exchange such as NYSE, AMEX and Nasdaq. Their results show that price adjustments due to cross-market information flows happen not only on the US exchange but also on the TSE. Consequently, the US exchange also contributes to price discover.

Bedi, Richards, and Tennant (2003) investigate the characteristics and stock price behaviour of six large DLCs existing in early 2003, three of which involve companies from the United Kingdom and the Netherlands (Royal Dutch/Shell, Unilever and Reed Elsevire) and the other three involve companies from the United Kingdom and Australia (Rio Tinto, BHP Billiton and Brambles Industries). Their results confirm Froot and Dabora's findings, which implies that substantial price divergences between Siamese twins and the co-movement with the national stock market indices are pervasive features of the pricing of DLCs. Sosner and Greenwood (2002) conduct a similar research studying changes in correlation following inclusions or exclusions from the Japanese Nikkei 225 index. Both authors find that when a stock is added to an index it becomes significantly more correlated with other stocks in that index, and less correlated with stocks that are not in the index.

Chan, Hameed and Lau (2003) examine the daily stock returns and trading volume of the Jardine Group during the pre-delisting and post-delisting period between 1994 and 1996. They find that the co-movement of Jardine stock returns with the Hong Kong market is lower and the co-movement with the Singapore market is higher after the delisting.

Ganon and Karolyi (2004) study 581 pairs of cross-listed/home-market shares of stocks from 39 countries around the world, most of which were ADRs, over the period from 1993 to 2002. Of the 39 countries, 19 were classified as emerging markets. They find that the premiums on the cross-listing shares relative to home-market shares can be as much as $66 \%$ and the relevant discounts can be as much as $87 \%$. Furthermore, returns on cross-listed stocks co-move more significantly with US market than their equivalent home market.

De Jong, Rosenthal and Van Dijk (2004) and De Jong, Rosenthal and Van Dijk (2009) study the risks and limits of arbitrage in dual-listed shares by investigating 12 DLCs which currently exist or have existed. They find substantially large deviations from theoretical pricing parity with average absolute price discrepancies for individual twins ranging from approximately $2.5 \%$ to nearly $12 \%$. They conclude that the influence of market 
indexing is the most plausible explanation for this phenomenon.

Chen, Tse and Williams (2009) investigate US market sentiment and the influence of trading location on pricing behavior by examining US-traded British American Depository Receipts (ADRs). They find that UK ADR returns are driven more by US market returns than US-traded UK market returns. In addition, US investors view UK ADRs more as domestic issues than foreign issues, which in turn implies the existence of US market sentiment for UK ADRs and underlies the importance of trading location on equity returns.

Besides local market indices and relevant currency changes that are largely examined by many authors, this paper investigates whether equity risk premium (ERP) is a possible factor that drives the price deviation between two parts of a twin. ERP is the excess return that an individual stock or the overall stock market provides over a risk-free rate. This excess return compensates investors for taking on the relatively higher risk of the equity market. Damodaran (2011) studying the determinants of ERP argue that ERP should reflect the risk aversion of investors who always require higher expected return for riskier investment, the health and predictability of the overall economy and the liquidity of the markets. Furthermore, Salomons and Grootveld (2002) study the ex-post ERP in a number of international markets and find that ERP in emerging markets is significantly higher than that in developed markets. Consequently, ERP may play a role in explaining the preference of investors over different markets which in turn may help explain the impact of trading locations on equity returns. This paper examines whether the excess return of the local overall stock market over a risk-free rate, or market risk premium (MRP), affects the deviations from price parity of dual-listed and cross-listed stocks.

\section{The Methodology and Model}

\subsection{Hypotheses}

The major research question of this paper is whether the location of trade affects equity returns. This study examines if the stock returns of dual-listed and cross-listed stocks companies are affected by the relative market indices, the relevant currency changes and the local market risk premium. Therefore the hypotheses to be tested are:

H1: The stock returns of dual-listed and cross-listed stocks companies are affected by the relative market indices.

H2: The stock returns of dual-listed and cross-listed stocks companies are affected by the relevant currency changes.

H3: The stock returns of dual-listed and cross-listed stocks companies are affected by the local market risk premium.

\subsection{Modeling Volatility}

This paper follows Froot and Dabora (1999)'s model but add the log changes of the Dutch and UK market risk premium into the right hand side of the regression equation as a new explanatory variable apart from Froot and Dabora's variables (which are log returns of the stock market indices and the log changes in the exchange rate).

Model 1. Testing for excess co-movement in dual-listed stocks

$$
\begin{aligned}
r_{\text {Dutch }, \mathrm{t}}-r_{\mathrm{UK}, \mathrm{t}} & =\alpha+\beta\left(\mathrm{r}_{\text {Dutch }, \mathrm{t}-1}-\mathrm{r}_{\mathrm{UK}, \mathrm{t}-1}\right)+\sum_{\mathrm{i}=0}^{1} \gamma_{\mathrm{i}}^{1} \mathrm{CBS}_{\mathrm{t}+\mathrm{i}}+\sum_{\mathrm{j}=-1}^{0} \gamma_{\mathrm{j}}^{2} \mathrm{FTSE}_{\mathrm{t}+\mathrm{j}}+\sum_{\mathrm{k}=-1}^{1} \delta_{\mathrm{k}} \mathrm{EX}_{\mathrm{t}+\mathrm{k}}+\lambda^{1} \mathrm{MRP}_{\text {Dutch,t }} \\
+ & \lambda^{2} \mathrm{MRP}_{\mathrm{uk}, \mathrm{t}}+\varepsilon_{\mathrm{t}}
\end{aligned}
$$

where $r_{D u t c h, t}$ and $r_{U K, t}$ are the log returns on day $\mathrm{t}$ of the Dutch and UK shares in their local currencies respectively. CBS and FTSE denote the log returns of the Dutch and UK stock market indices. EX represents the log changes in the exchange rate Guilder(Euro)/Pound and MRP denotes the log changes in the market risk premiums of the Dutch and UK stock markets.

This paper extends Froot and Dabora's (1999) earlier effort by including cross-listed stocks in the analysis. In order to test the co-movement between cross-listed stocks and its home-market counterparts, the following regression equation is used:

Model 2. Testing for excess co-movement in cross-listed stocks 


$$
\begin{aligned}
\mathrm{r}_{\mathrm{US}, \mathrm{t}}-\mathrm{r}_{\mathrm{H}, \mathrm{t}} & =\alpha+\beta\left(\mathrm{r}_{\mathrm{US}, \mathrm{t}-1}-\mathrm{r}_{\mathrm{H}, \mathrm{t}-1}\right)+\sum_{\mathrm{i}=-1}^{1} \gamma_{\mathrm{iS}}^{\mathrm{US}} \mathrm{SP} 00_{\mathrm{t}+\mathrm{i}}+\sum_{\mathrm{j}=-1}^{1} \gamma_{\mathrm{j}}^{\mathrm{H}} \operatorname{HomeIndex}_{\mathrm{t}+\mathrm{j}}+\sum_{\mathrm{k}=-1}^{1} \delta_{\mathrm{k}} \mathrm{EX}_{\mathrm{t}+\mathrm{k}} \\
& +\lambda^{\mathrm{US}} \mathrm{MRP}_{\mathrm{US}, \mathrm{t}}+\lambda^{\mathrm{H}} \mathrm{MRP}_{\mathrm{H}, \mathrm{t}} \\
& +\varepsilon_{\mathrm{t}}
\end{aligned}
$$

where $r_{U S, t}$ and $r_{H, t}$ are the log returns on day $\mathrm{t}$ of the US shares and the home-market (the Dutch or UK) shares in their local currencies respectively. SP500 and HomeIndex denote the log returns of the US and the home stock market indices. EX represents the log changes in the relevant exchange rate and MRP denotes the log changes in the market risk premiums of the US and home stock markets.

\subsection{Data}

Daily stock prices and total returns in local currency are obtained from Datastream. The sample period for Royal Dutch Shell and Unilever is January 1, 1980 to October 3, 2002. The sample period for Reed Elsevier is from January 1, 1993 to October 3, 2002. These sample periods end 20 trading days before the announcement date of the share unification in the case of Royal Dutch/Shell since its stock price rapidly converged after the unification announcement.

Daily domestic stock market indices are also collected from Datastream. For domestic stock market indices we use the FTSE Allshare index for the UK, the S\&P 500 index for the US, and the CBS Allshare index for the Netherlands. The use of standard market indexes potentially creates a bias because Royal Dutch and Unilever NV are in the S\&P500 and Shell, Unilever PLC and Elsevier NV are in the FTSE. However, Froot and Dabora (1999) and Bedi, Richards and Tennant (2003) find that the effect of this bias is minor since each firm bears a relatively small weight in its index. Nevertheless, Royal Dutch is by far the largest native stock traded on the Amsterdam Exchange. Therefore, to eliminate any bias, Royal Dutch is removed from the standard CBS Allshare index. Daily exchange rate data are also obtained from Datastream. Froot and Dabora (1999) argue that exchange-rate changes and local currency stock returns show little correlation. As a result, any error in exchange-rate changes from non-synchroneities will not bias the coefficients.

To calculate the MRPs in the Netherlands, the UK and the US, the difference between the log return of the local index and the 3-month deposit rate in each country during the sample periods is computed. These data can also be downloaded from Datastream. The MRP variable in the regression equation is the daily log changes of the calculated MRPs.

\section{Results}

\subsection{Dual-listed Stocks}

Table 2 reports estimation results of equation (1) for three DLCs over the two sample periods 1980-1995 and 1996-2002. Since these results involve rolling regression using overlapping data, Newey-West standard errors is employed in order to correct heteroskedasticity and autocorrelation. The reported coefficients on market indices and exchange rate represent the sum of the coefficients on the lead, lag and the contemporaneous variables.

The results are consistent with Froot and Dabora's findings about the co-movement between twin price differentials and market indices as well as the relevant currency changes. Almost all coefficients, except for those on market risk premium, are significantly different from 0 at the $1 \%$ and of the expected sign. This means that the null hypothesis of perfect market integration is strongly rejected for all three twins. In all cases, the dependent variables are defined as the return of the Dutch part less the return on the UK part. Therefore, positive coefficients on the Dutch market index suggest that a positive shock in the Dutch market leads to an increase in the relative price of Dutch shares whereas negative coefficients on UK market index indicate that a positive shock in the UK market leads to an increase in the relative price of UK shares and thus a decrease in the return differentials.

The economic importance of the market indices and currency changes is substantial, as their coefficients are considerably high. Although the coefficient on CBS index for Unilever for the period 1980-1995 of -0.0066 has unexpected sign, it is not significantly different from 0 even at the $10 \%$ level. Other coefficients on CBS index are all significant at the 1\% level and vary between 0.268 for Reed Elsevier during 1980-1995 and 0.412 for Reed Elsevier during 1996-2002. The coefficients on FTSE index ranges from -0.242 for Reed Elsevier during 1980-1995 to -0.568 for Unilever during 1980-1995 and are all significant. This implies, for example, that a $1 \%$ increase in the CBS index increases the relative return of Elsevier versus the relative return of Reed International by 41 basis points and a 1\% increase in the FTSE index decreases the relative return of Unilever NV versus 
Unilever PLC by 57 basis points. The coefficients on the currency changes vary between -0.507 and -0.915 . They are all significantly different from 0 at $1 \%$ level and of the expected negative sign. For example, $\delta=-0.915$ implies that a $1 \%$ appreciation of guilder against pound increases the relative return of Royal Dutch versus that of Shell by 91 basis points.

The null hypothesis for market risk premium cannot be rejected at $10 \%$ level. The coefficients on Dutch MRP do not have the expected positive sign. In addition, only two out of six cases the coefficients are significant at $1 \%$ level, but their economic importance is negligible. Similarly, regressing equation (1) provides mixed results for the coefficients on UK MRP. Two out of six cases have the expected negative coefficients and two other cases are significant at $1 \%$ level but with unexpected sign and minor economic importance. This paper concludes that market risk premium does not play a role in explaining the mispricing in DLCs.

However, the estimation results for MRP are not completely reliable. Aswath Damodaran (2011) argues that the risk premium can vary widely across approaches and it is difficult to choose the "right" number to use in analysis. The author then suggests that the choice of a premium depends on the forecast period, whether "you believe markets are efficient and whether you are required to be market neutral in your analysis". Furthermore, there exists the Equity risk premium puzzle, a phenomenon that describes the abnormally high historical risk premium, about 6\%, in the past century (Damodaran, 2011). According to earlier studies, this premium is too large to reflect a proper level of compensation required by risk-averse investors, which implies an implausibly high level of risk-aversion among investors.

Table 2. Testing for excess co-movement in dual-listed stocks - Netherlands vs. UK (1980-2002)

\begin{tabular}{|c|c|c|c|c|c|c|c|c|}
\hline DLCs & $\mathrm{R}^{2}$ & Constant & Lagged dep. Var & CBS & FTSE & EX & $\mathrm{MRP}_{\text {Dutch }}$ & $\mathrm{MRP}_{\mathrm{UK}}$ \\
\hline \multicolumn{9}{|c|}{ A: Sample period 1980-1995 } \\
\hline Royal Dutch Shell & 0.23 & 0.00012 & $-0.172 * * *$ & $0.293 * * *$ & $-0.444 * * *$ & $-0.759 * * *$ & $-5.15 \mathrm{E}-05^{* * *}$ & 4.31E- $05 * * *$ \\
\hline Unilever & 0.18 & 0.00026 & $-0.118^{* * *}$ & -0.0066 & $-0.568 * * *$ & $-0.507 * * *$ & $-5.51 \mathrm{E}-05^{* * *}$ & 4.13E-05 \\
\hline Reed Elsevier & 0.27 & 0.00036 & $-0.254 * * *$ & $0.282 * * *$ & $-0.242 * * *$ & $-0.875^{* * *}$ & $-1.06 \mathrm{E}-05$ & $7.55 \mathrm{E}-05^{* * *}$ \\
\hline \multicolumn{9}{|c|}{ B: Sample period 1996-2002 } \\
\hline Royal Dutch Shell & 0.30 & -0.00013 & $-0.311 * * *$ & $0.268 * * *$ & $-0.427 * * *$ & $-0.915^{* * *}$ & $-1.58 \mathrm{E}-05$ & $-7.32 \mathrm{E}-06$ \\
\hline Unilever & 0.21 & -0.00014 & $-0.383 * * *$ & $0.369 * * *$ & $-0.460 * * *$ & $-0.891 * * *$ & $-5.91 \mathrm{E}-06$ & $6.08 \mathrm{E}-06$ \\
\hline Reed Elsevier & 0.20 & -0.00014 & $-0.332 * * *$ & $0.412 * * *$ & $-0.538 * * *$ & $-0.716^{* * *}$ & $-2.07 \mathrm{E}-05$ & $-8.60 \mathrm{E}-07$ \\
\hline
\end{tabular}

The $\mathrm{R}^{2}$ of the regression ranges from $18 \%$ to $30 \%$, indicating that 18 to 30 percent of daily return differentials can be explained by the lagged dependent variable, the local stock market indices and the exchange rate.

Comparing the results of the two examined periods confirms the persistence of the co-movement between the return differentials and the local market indices as well as the relevant currency changes. In addition, the co-movement presented in the second period appears to be stronger than that in the first period.

\subsection{Cross-listed Stocks}

This paper extends Froot and Dabora's (1999) earlier effort by including cross-listed stocks in the analysis. Table 3 and 4 present estimation results of equation (2) for 3 pairs of Dutch-US cross-listed stock and 3 pairs of UK-US cross-listed stock, respectively, for two periods 1980-1995 and 1996-2002.

The null hypothesis of zero coefficients on market indices and currency changes is strongly rejected for almost all cases, except for the coefficient on FTSE for Reed International during 1980-1995. Almost all coefficients are of expected sign, except for that on SP500 in the case of Reed International during the same period. This could be explained partly by the fact that Reed and Elsevier ADRs trade less intensively in the US in comparison to the other ADRs in the sample and they weren't listed on US stock exchange until late 1994, long time after the listing of other ADRs in the sample.

The economic importance of the market indices and exchange rates is substantial. The "excess return" measures, or the intercept coefficients, are very close to zero, ranging from -0.034 basis points to 0.023 basis points per day.

Comparing the results of Table 3 with those of Table 4 gives some indication that the degree of excess 
co-movement is higher for US-Dutch pairs than US-UK pairs, which supports Suh (2003)'s findings that ADRs from emerging countries with fragmented markets and foreign ownership restrictions tend to trade at a higher premium to their underlying shares than those from developed countries.

Similar to Ganon and Karolyi (2004), the dependent variables in equation (2) are defined as the return on the US shares less the return on the home-market shares. This paper's results generally confirm their findings about the close-to-zero intercept coefficients, negative and significant lagged dependent coefficients, and negative and significant net exposure to the home market. The net exposure to the US market and that to the exchange rate are also positive; however unlike Ganon and Karolyi (2004)'s results, they are all of significant at the 1\% level. Additionally, this study shows similar results about the small and insignificant estimates for many of the lagging and leading market indices and currency changes, which indicates the dominance of the contemporaneous effects.

Table 3. Testing for excess co-movement in cross-listed stocks - US vs. Netherlands

\begin{tabular}{|c|c|c|c|c|c|c|c|c|}
\hline DLCs & $\mathrm{R}^{2}$ & Constant & Lagged dep. Var & SP500 & CBS & EX & $\mathrm{MRP}_{\mathrm{US}}$ & $\mathrm{MRP}_{\text {Dutch }}$ \\
\hline \multicolumn{9}{|c|}{ A: Sample period 1980-1995 } \\
\hline Royal Dutch & 0.63 & $-4.14 \mathrm{E}-05$ & $-0.354 * * *$ & $0.315 * * *$ & $-0.125^{* * *}$ & $-1.269 * * *$ & $2.68 \mathrm{E}-06$ & $3.04 \mathrm{E}-05^{* * *}$ \\
\hline Unilever NV & 0.44 & -0.00034 & $-0.209 * * *$ & $0.392 * * *$ & $-0.273 * * *$ & $-1.091 * * *$ & $3.67 \mathrm{E}-05 * * *$ & $2.96 \mathrm{E}-06$ \\
\hline Elsevier & 0.46 & -0.00012 & $-0.413 * * *$ & $0.315 * * *$ & $-0.678 * * *$ & $-1.249 * * *$ & $-3.25 \mathrm{E} 05$ & $-2.73 \mathrm{E}-05$ \\
\hline \multicolumn{9}{|c|}{ B: Sample period 1996-2002 } \\
\hline Royal Dutch & 0.48 & $-9.49 \mathrm{E}-05$ & $-0.448 * * *$ & $0.445^{* * *}$ & $-0.916^{* * *}$ & $-1.208^{* * *}$ & $2.38 \mathrm{E}-06$ & $1.13 \mathrm{E}-05$ \\
\hline Unilever NV & 0.35 & $-9.15 \mathrm{E}-05$ & $-0.432 * * *$ & $0.347 * * *$ & $-0.234 * * *$ & $-1.111 * * *$ & $1.59 \mathrm{E}-06$ & $-8.14 \mathrm{E}-06$ \\
\hline Elsevier & 0.41 & $-1.93 \mathrm{E}-05$ & $-0.444 * * *$ & $0.170^{* * *}$ & $-0.145^{* * *}$ & $-1.376^{* * *}$ & $-9.50 \mathrm{E} 06$ & $1.31 \mathrm{E}-05$ \\
\hline
\end{tabular}

Table 4. Testing for excess comovement in cross-listed stocks - US vs. UK

\begin{tabular}{|c|c|c|c|c|c|c|c|c|}
\hline DLCs & $\mathrm{R}^{2}$ & Constant & Lagged dep. Var & SP500 & FTSE & EX & $\mathrm{MRP}_{\mathrm{US}}$ & $\mathrm{MRP}_{\mathrm{UK}}$ \\
\hline \multicolumn{9}{|c|}{ A: Sample period 1980-1995 } \\
\hline Shell & 0.54 & $-1.73 \mathrm{E}-05$ & $-0.387 * * *$ & $0.202 * * *$ & $-0.135 * * *$ & $-1.277 * * *$ & $-2.84 \mathrm{E}-06$ & 4.65E-07 \\
\hline Unilever PLC & 0.31 & $-8.53 \mathrm{E}-06$ & $-2.603 * * *$ & $0.252 * * *$ & $-0.267 * * *$ & $-0.957 * * *$ & $-5.29 \mathrm{E}-06$ & $-1.35 \mathrm{E}-05$ \\
\hline Reed & 0.24 & 0.00023 & $-0.374 * * *$ & $-0.154 * * *$ & -0.542 & $-0.685 * * *$ & $1.93 \mathrm{E}-05$ & $-9.28 \mathrm{E}-06$ \\
\hline \multicolumn{9}{|c|}{ B: Sample period 1996-2002 } \\
\hline Shell & 0.44 & $-9.73 \mathrm{E}-05$ & $-0.400 * * *$ & $0.375 * * *$ & $-0.453 * * *$ & $-1.224 * * *$ & $-1.19 \mathrm{E}-05$ & $-3.95 \mathrm{E} 06$ \\
\hline Unilever PLC & 0.41 & -0.00016 & $-0.339 * * *$ & $0.257 * * *$ & $-0.281 * * *$ & $-1.209 * * *$ & $1.06 \mathrm{E}-06$ & $-7.54 \mathrm{E}-07$ \\
\hline Reed & 0.23 & $1.64 \mathrm{E}-05$ & $-0.384 * * *$ & $0.124 * * *$ & $-0.277 * * *$ & $-1.005 * * *$ & $5.70 \mathrm{E}-07$ & $-4.84 \mathrm{E}-06$ \\
\hline
\end{tabular}

The estimates of the MRP again exhibit unexpected signs, small magnitude, and the vast majority of them are insignificantly different from zero at conventional levels. These results of cross-listed stocks are similar to those of dual-listed stocks illustrated above, which support the conclusion that market risk premium do not play a role in the mispricing phenomenon.

The $\mathrm{R}^{2}$ of this regression varies between $23 \%$ and $63 \%$ which is much higher than the $\mathrm{R}^{2}$ of the regression of equation (1). This implies that the explanatory power of our regression for equation (2) is surprisingly high, and that the lagged dependent variable, the local stock market indices and the exchange rate help explain the price discrepancies of cross-listed stocks better than that of dual-listed stocks.

\section{Summary and Conclusions}

This paper presents evidence of an apparent violation of the law of one price: the significant deviations from price parity of stocks that trade simultaneously in different markets. The regression results show that the return differentials on the dual-listed and cross-listed companies exhibit co-movements relative to local market index returns and the relevant currency changes, and that these co-movements are related to the primary trading 
location of the respective shares. Therefore, the location of trade effect captures part of the mispricing. This sort of co-movement cannot be assigned to fundamental factors but is likely to be explained by sentiment-based theories. Furthermore, by extending Foot and Dabora (1999)'s examined period, this paper shows that this sort of mispricing and location of trading effect are pervasive phenomena. Market risk premium appears to be insignificant in explaining the co-movement in this paper's sample of DLCs.

However, there are some limitations to this research that should be mentioned. Firstly, there are many direct and indirect costs which are difficult to differentiate regardless of the technological advances taking places among the depositary banks and independent brokers/dealers to smooth the process (Ganon \& Karolyi, 2004). They are transaction costs, regulatory restrictions on foreign ownership, ADR/ordinary convertibility that have become challenges to any research analysis. Secondly, the frequency of this study is daily, which may induce cross-autocorrelations since the effect of stale prices and quotes reduces as the return horizon increases. Finally, the unbalance in the sample period due to the late establishment of Reed Elsevier is likely to affect this paper's inferences.

Indexing is viewed as an important source of price disparities. To the degree that indexing is important in any market, the price of one firm in the DLC will rise relative to parity if that firm is included in an index. This impact can be seen when two non-US companies in their sample - Royal Dutch NV and Unilever NV - were eliminated from the S\&P 500 in 2002. After the decision was announced, stock prices of these two companies dropped relative to their UK counterparts in the weeks leading up to the removal. Indexing therefore can be a considerable portfolio strategy in the US.

There exists a question of why arbitrageurs are unable to close the price gap between these stocks. Although arbitrage strategies in DLCs have negligible fundamental risk and low systematic risk, they are characterized by high idiosyncratic risk because of a high degree of uncertainty about convergence of the mispricing. In addition, capital restrictions and information barriers impede corrective arbitrage and thus perpetuate deviations from parity.

\section{References}

Bedi, J., Richards, A., \& Tennant, P. (2003). The characteristics and trading behavior of dual-listed companies. Reserve Bank of Australia working paper. $\mathrm{http} / / / \mathrm{dx}$. doi.org/10.2139/ssrn.418500

Bodurtha, J. N. Jr., Kim, D., \& Lee, C. M. C. (1995). Closed-End country funds and U.S. market sentiment. Review of Financial Studies, 8, 879-918. http://dx.doi.org/10.1093/rfs/8.3.879

Chan, K., Hameed, A., \& Lau, S. (2003). What if trading location is different from business location? Evidence from the Jardine Group. Journal of Finance, 58, 1221-1246. http://dx.doi.org/10.2139/ssrn.293576

Chen, J., Tse, Y., \& Williams, M. (2009). Trading location and equity returns: Evidence from US trading of British cross-listed firms. Journal of International Financial Markets. http://dx.doi.org/10.1016/j.intfin. 2009.05.001

De Jong, A., Rosenthal, L., \& Van Dijk, M. (2004). The limits of arbitrage: Evidence from dual-listed companies. Erasmus University working paper.

De Jong, A., Rosenthal, L., \& Van Dijk, M. (2009). The risk and return of arbitrage in Dual listed companies. Erasmus University working paper. http://dx.doi.org/10.1093/rof/rfn031

Damodaran, A. (2011). Equity Risk Premiums (ERP): Determinants, Estimation and Implications. Financial Markets, Institutions \& Instruments, 18, 289-370. http://dx.doi.org/10.2139/ssrn.1769064

Eun, C., \& Sabberwal, S. (2002). Cross-border listing and price discovery: Evidence from U.S. listed Canadian stocks. Journal of Finance, 58, 549-577. http://dx.doi.org/10.1111/1540-6261.00537

Froot, K. A., \& Dabora, E. (1999). How are stock prices affected by the location of trade? Journal of Financial Economics, 53, 189-216. http://dx.doi.org/10.3386/w6572

Froot, K. A., \& Perold, A. F. (1997). Global equity markets: The case of Royal Dutch and Shell. Harvard Business School Case, 9, 296-077.

Gagnon, L., \& Karolyi, G. A. (2004). Multi-market trading and arbitrage, unpublished working paper. Queens University, Ohio State University.

Lamont, O. A., \& Thaler, R. H. (2003). Anomalies the Law of One Price in Financial Markets. Journal of Economic Perspectives, 17(4), 191-202. http://dx.doi.org/10.1257/089533003772034952

Rosenthal, L., \& Young, C. (1990). The seemingly anomalous price behavior of Royal Dutch/Shell and Unilever 
N.V./PLC. Journal of Financial Economics, 26, 123-141. http://dx.doi.org/10.1016/0304-405X(90)90015-R

Salomons, R., \& Grootveld, H. (2002). The equity risk premium: Emerging versus developed markets. University of Groningen SOM Working Paper, 02E45. http://dx.doi.org/10.2139/ssrn.535662

Sosner, N., \& Greenwood, R. (2002). Trade and the Comovement of Stock Returns: Evidence from Japan. http://dx.doi.org/10.2139/ssrn.305059

Suh, J. (2003). ADRs and U.S. Market Sentiment. The Journal of Investing, 12, 87-95. http://dx.doi.org/10.3905/ joi.2003.31957

\section{Appendix}

Log deviations from price parity of dual-listed and cross-listed shares

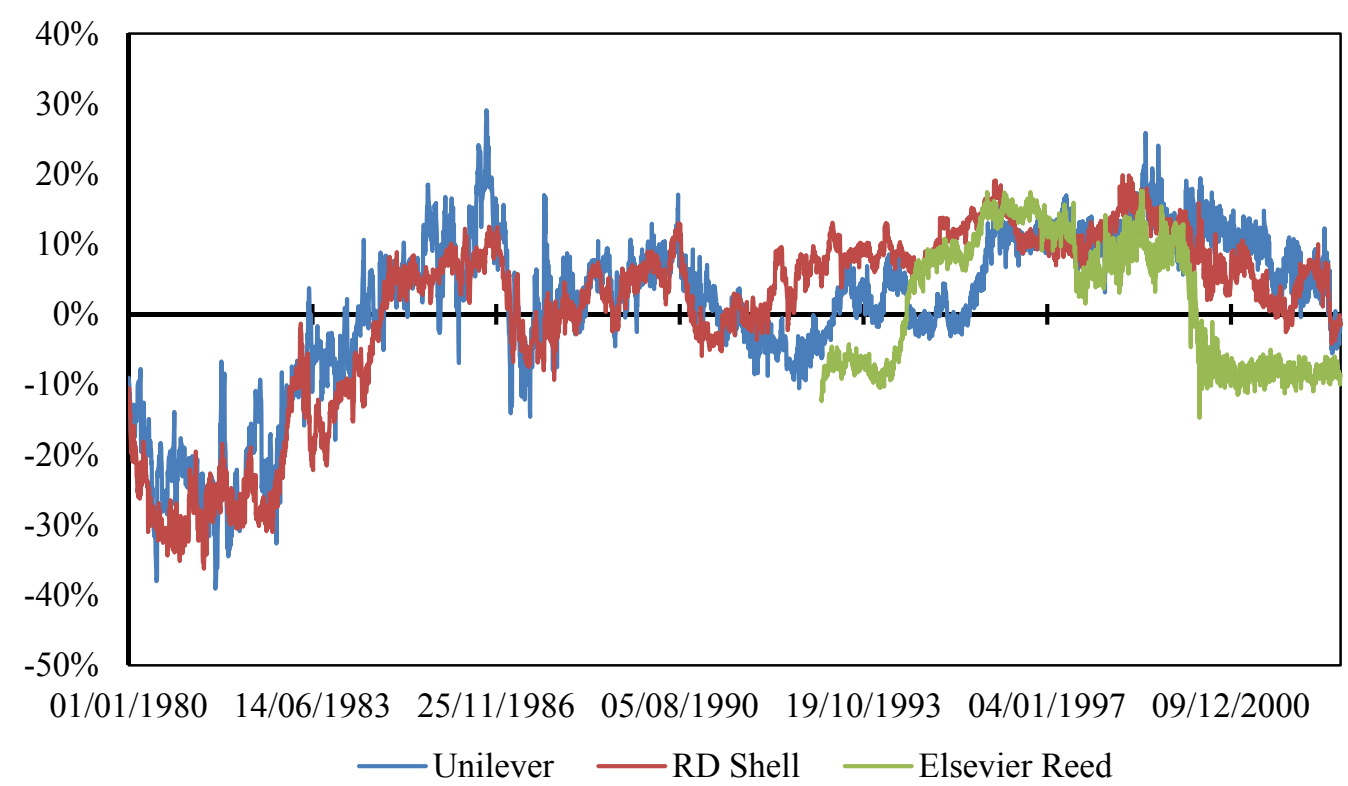

Figure 1. Log deviations from price parity of dual-listed shares

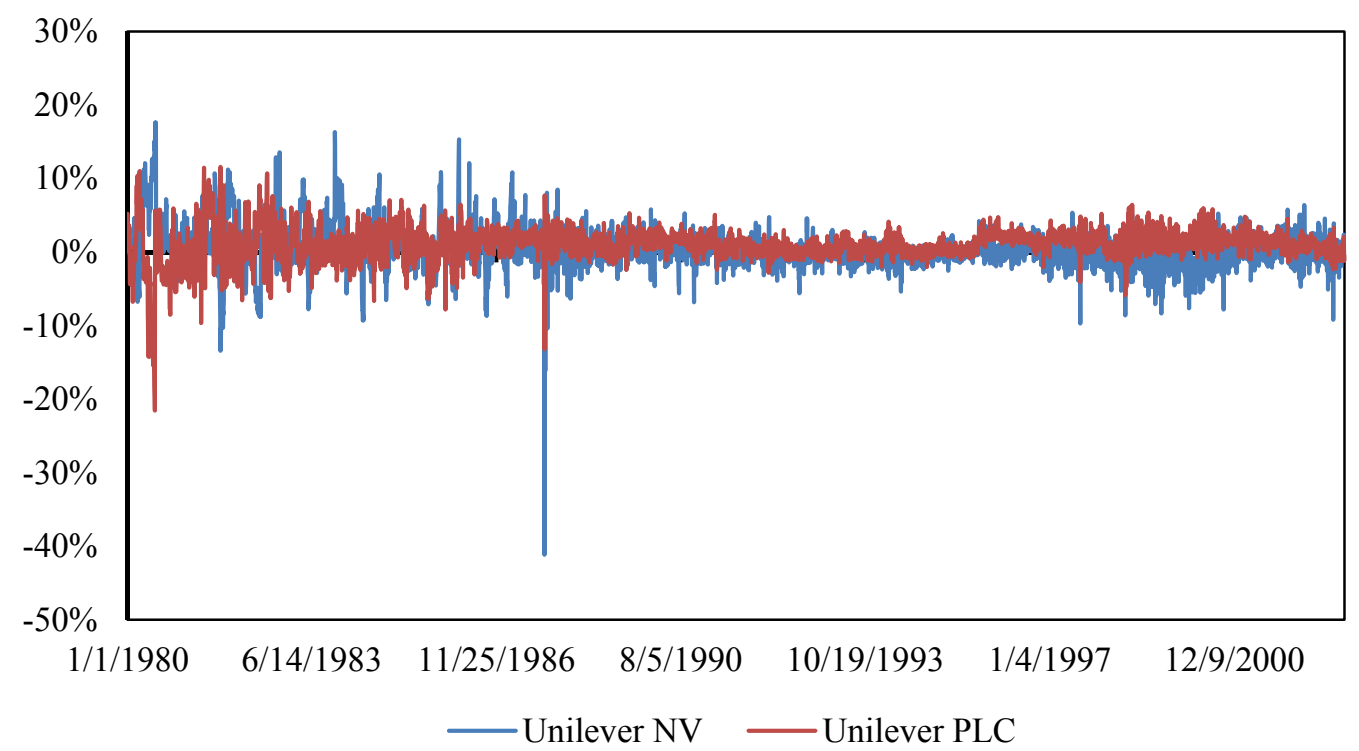

Figure 2. Log deviations from price parity of crossed-listed shares: Unilever NV vs. Unilever PLC 


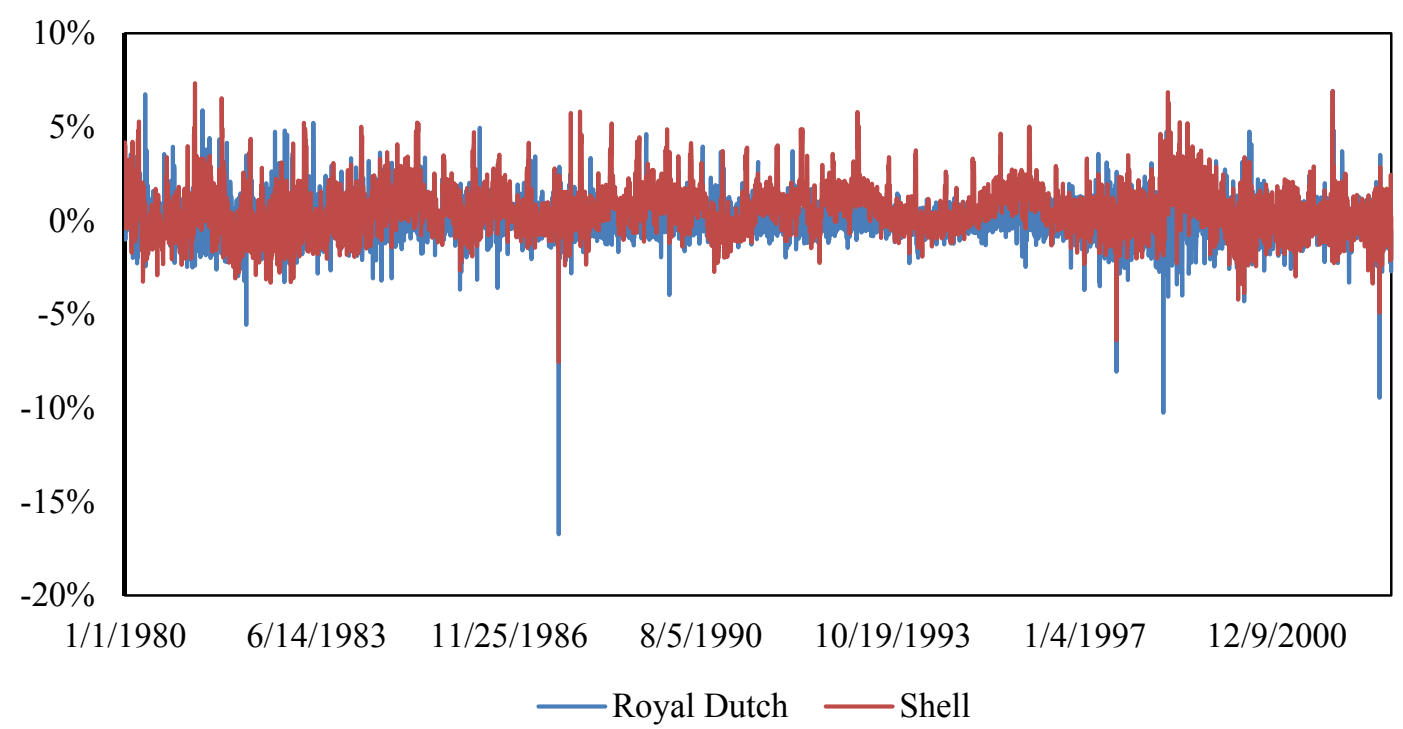

Figure 3. Log deviations from price parity of crossed-listed shares: Royal Dutch vs. Shell

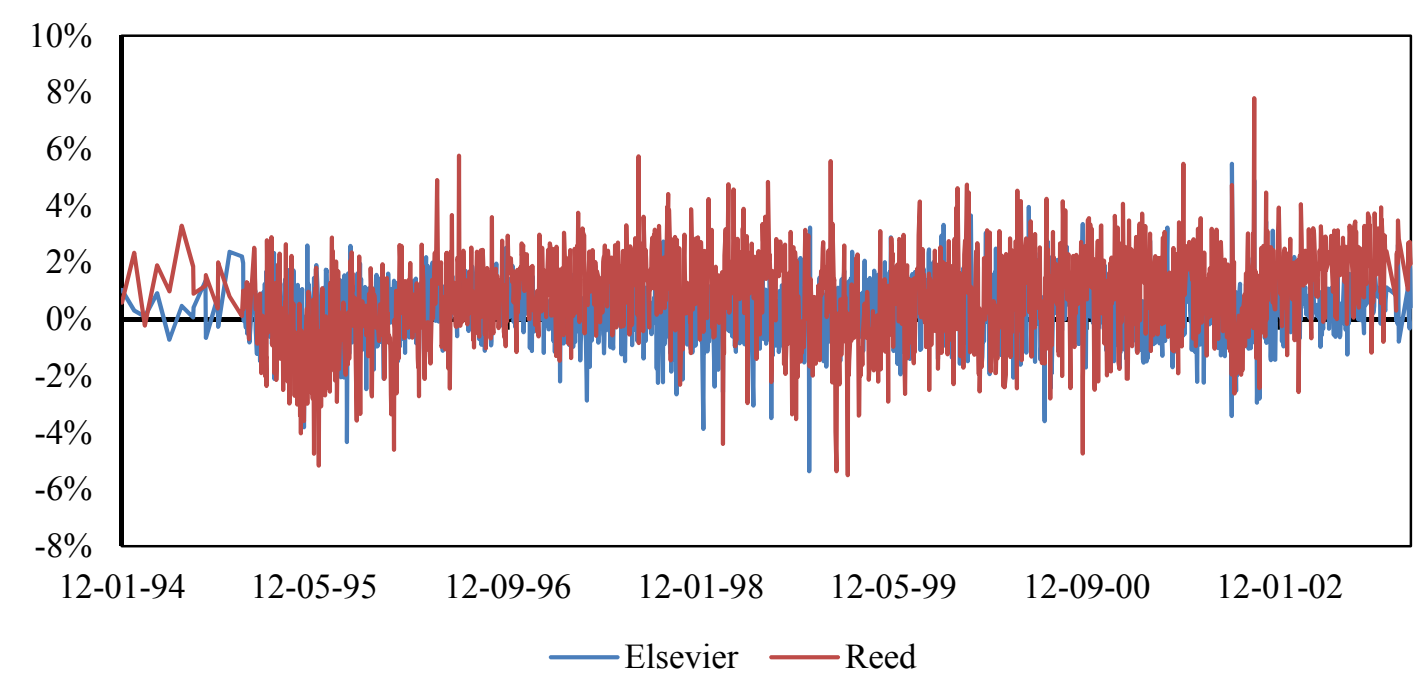

Figure 4. Log deviations from price parity of crossed-listed shares: Elsevier vs. Reed

\section{Copyrights}

Copyright for this article is retained by the author(s), with first publication rights granted to the journal.

This is an open-access article distributed under the terms and conditions of the Creative Commons Attribution license (http://creativecommons.org/licenses/by/4.0/). 